\title{
Emotional Determinants of Categorical Accentuation
}

\author{
Saša Drače and Mia Čehajić \\ University of Sarajevo, Faculty of Philosophy, Sarajevo, Bosnia and Herzegovina
}

\begin{abstract}
The present study aimed to provide preliminary evidence for the role of uncertainty related emotions in categorical accentuation. Participants had to estimate the length of lines varying in length, which depending on the conditions were or were not associated with categorical labels. To explore the emotional determinants of categorical accentuation we included additional label condition, in which participants were induced to feel fear (i.e. the emotion theoretically defined by the appraisal of low certainty). Consistent with the past research the results revealed a classic accentuation effect with participants in label condition showing higher differentiation at category boundaries compared to those in no label condition. More importantly, this effect was strengthened in the condition in which participants were induced with fear suggesting that uncertainty-related emotions could play an important role in the accentuation phenomenon.
\end{abstract}

Keywords: categorical accentuation, emotion, cognitive appraisal, uncertainty

\section{Introduction}

More than half a century ago, research in social psychology has provided evidence that categorization of physical or social objects produces perceptual accentuation of differences between categories on dimensions believed to be associated with the categorization (for review see Hugenberg \& Sacco, 2008). In a classic demonstration of this phenomenon, Tajfel and Wilkes (1963) asked participants to judge a series of lines that varied in monotonically decreasing length. In one condition no category labels for lines were given. In the second condition, lines were randomly associated with two different labels. Finally, in the third condition lines were associated with two different labels such that long lines were given one label and short lines were given another label. This last condition simulated an explicit comparison context for both categories, and results showed that in this condition the difference between perceivers' estimates of the lengths of the two stimuli nearest the category boundary was exaggerated (compared with the other two conditions). Since this seminal work similar accentuation effect has been

Drače Saša, Faculty of Philosophy, Franje Račkog 1, 71000 Sarajevo, Bosnia and Herzegovina. E-pošta: dracesasa@gmail.com 
successfully replicated within a large range of physical and social stimuli (e.g., Eiser \& Van der Pligt, 1982; Foroni \& Rothbart, 2011; Goldstone, 1995; Krueger \& Clement, 1994; Levin \& Banaji, 2006), and has proven to persist even when the category labels have been removed (Foroni \& Rothbart, 2013).

Recent empirical evidence has suggested that the perceptual accentuation of categorical differences may be strengthened when the task is more complex, and people are presumably less certain of their judgments. For instance, using classic Tajfel and Wilkes's (1963) paradigm, Corneille and his associates (Corneille et al., 2002) asked Belgian and American participants to perform line estimate task using either familiar or unfamiliar measurement units. Consistent with the original findings by Tajfel and Wilkes (1963) participants' differentiation at category boundaries was higher when the lines were systematically categorized than when they were not. Crucially, this effect was stronger when participants reported their estimates in an unfamiliar measurement unit (i.e., Belgian participants using inches, and American participants using centimetres), suggesting that the categorical accentuation is more likely to emerge under conditions of higher uncertainty of judgment (also see Petersen et al., 2014; Sherman et al., 2009).

In the present paper, we extend this research by focusing on the emotional determinants of the accentuation effect. More precisely, we propose that emotions, which embody an underlying appraisal of uncertainty about the world, will lead people to feel more uncertain which in turn should enhance the perception of between-category differences. In line with this idea, we think the AppraisalTendency Framework (ATF; Lerner \& Keltner, 2001) could provide an interesting theoretical background wherein these emotional effects may be studied and explained.

Drawing on cognitive appraisal models of emotion elicitation (e.g., Smith \& Ellsworth, 1985) ATF proposes that the appraisal dimensions underlying the triggering of specific emotion can also influence the appraisal of the current situation. The ATF summarizes these processes as "appraisal tendencies". For instance, fear and anger, although negative in valence, differ markedly in the appraisal dimension of certainty, characterized by the feeling of being certain, understanding what is happening, and predicting what will happen next. Whereas fear is defined by an appraisal of low certainty, anger is defined by an appraisal of high certainty. On the other side, happiness, although of positive valence, is associated with an elevated sense of certainty, just like anger (Smith \& Ellsworth, 1985). Accordingly, these appraisals would lead individuals who experience anger to consider their environment as certain whereas those experiencing fear would assess the environment as being uncertain. Consequently, appraisal tendencies activated by each specific emotion are expected to play a determining role in shaping the perception of a subsequent unrelated situation. In line with this idea, Tiedens and Linton (2001) conducted a series of studies and found that participants, who were induced to feel fear or worry reported a higher level of task uncertainty than those 
who were induced to feel happiness or disgust. Moreover, these differences in the certainty appraisal mediated the effect of corresponding emotions on information processing (e.g., reliance on stereotypes). Similar results were observed in various contexts involving the effects of discrete emotions on the risk perception (e.g., Lu et al., 2013), decision-making (e.g., Bagneux et al., 2012) or beliefs in conspiracy theories (e.g., Whiston et al., 2015).

By extension, we expected that the emotions, defined by the appraisal of low certainty, should exert corresponding influence on the perceptual accentuation of categorical differences. To test this hypothesis, we used the classic Tajfel and Wilkes' (1963) paradigm in which participants were asked to estimate the length of each of the eight lines under one of the two main conditions: no label condition in which no category labels were given, and label condition, in which letter " $a$ " was systematically paired with each of four shorter lines, while the letter "b" was systematically paired with each of four longer lines. To explore the emotional determinants of categorical accentuation we included additional label condition in which participants were exposed to the experimental induction of fear. As mentioned before, previous research has provided converging evidence that fear is strongly related to the cognitive appraisal of uncertainty (Smith \& Ellsworth, 1985; Tiedens $\&$ Linton, 2001). Thus, by choosing fear we expected to create the optimal conditions in which the hypothetical effect of emotion could most likely emerge. Consistent with the original work by Tajfel and Wilkes (1963), we expected that the presence of meaningful categorical label would increase the accentuation of differences between categories. Crucially, we also predicted that this accentuation effect would be significantly strengthened in the condition in which participants were supposed to feel uncertain due to fear induction.

\section{Method}

\section{Participants}

One hundred and thirty-nine ${ }^{1}$ psychology undergraduates (118 women, $M$ age $=20.59$ years; $S D=1.74$ ) took part in exchange for course credit. Three were excluded for failing to complete the line estimates, totalling to 136 participants (116 women, $M$ age $=20.58$ years; $S D=1.75$ ) which were assigned to one of three experimental conditions: no-Label $(n=43)$, Label $(n=46)$ or the Label-fear $(n=47)$.

\footnotetext{
${ }^{1}$ We decided beforehand to collect at least 135 participants. This ensured $80 \%$ power to detect a medium-sized effect for the planned comparison testing our model as calculated by the PANGEA app. Because of group assignments, we ended up with more participants.
} 


\section{Materials and Procedure}

Participants took part in groups of 4 in a large laboratory room $(4 \mathrm{~m} \mathrm{x} 6 \mathrm{~m})$. They were seated in front of a personal computer without the possibility to interact with each other. In order to disguise the purpose of the research, the experimenter described the study as examining eyewitness testimony, which consisted of the two stages. Stage one involved viewing a short movie / a series of pictures, which the participants were asked to look at very carefully as they would be tested on what they had seen at the end of the experiment. Stage two consisted of an unrelated perception test, ostensibly to simulate real eyewitness report situations, in which there was a time delay between seeing an event and describing it, during which the witness's attention was diverted by other stimuli.

During the first stage participants in the label fear-induction condition were exposed to a short excerpt (4 minutes) from the horror movie The Blair Witch Project (Schaefer et al., 2010). On the other side, participants in the classic label and no label conditions spent the same amount of time looking at a series of standardized and neutral pictures from the International Affective Picture System (IAPS; Lang et al., $1995)^{2}$.

Once they finished watching video excerpt (or pictures) participants rated to what extent they felt various affective states (gleeful, angry, anxious, downhearted, cheerful, scared, active, joyful, interested, nervous, sad, pleasant, unpleasant; 1 = not at all; $4=$ very much). In line with past research (Lerner \& Keltner, 2001) responses on items scared, anxious, and nervous were averaged to create a reliable index of fear (Cronbach's alpha $=.76$ ). Then participants were introduced to the second stage, which corresponded to the main task (i.e., the estimates of line lengths). At this point, the experimental procedure followed similar steps as in the study by Corneille et al. (2002). Participants were told that they would be presented with a series of straight lines whose length they would have to estimate as precisely as possible just by looking at them. It is important to note that, unlike past research in which lines were presented in individual booklets, in the present case the evaluation of stimuli was computer-assisted using E-Prime 2.0 software. Thus, participants were first presented with 10 lines, each associated with an objective length indication (in centimetres). These lines remained on the computer screen for 30 seconds so the participants could familiarize themselves with the objective length proportion of stimuli in centimetres. Then prior to the judgment task participants were presented twice with a full series of lines they would have to estimate in the main task. These lines were drawn diagonally on the centre of a computer screen. The lengths of the lines used in the task decreased linearly from the longest line $(\mathrm{L} 8=11.4 \mathrm{~cm})$ to the

\footnotetext{
2 The IAPS codes for the pictures we used are: 2190, 2385, 2514, 2516, 2749, 2840, 2890, 5510, 5531, 5534, 7004, 7006, 7009, 7010, 7020, 7050, 7160, 7170, 7175, 7185, 7187, 7207, 7211, 7217, 7233, 7235 .
} 
shortest line $(\mathrm{L} 1=7.4 \mathrm{~cm})$. As in previous studies (i.e., Corneille et al., 2002; Tajfel $\&$ Wilkes, 1963), the following order was used for these initial presentations: L5, L6, L7, L8, L1, L2, L3, L4, then, L4, L3, L2, L1, L8, L7, L6, L5.

Then participants were presented with the judgment task in which they estimated each of the eight lines six times. Each line remained on screen for 8 seconds after which it was replaced by the answer box on the computer screen in which participants typed in their length estimate using the keyboard. After 48 trials participants were thanked and debriefed in accordance with ethical standards. For each participant we calculated a single accentuation score, which corresponded to the mean difference (in centimetres) between estimates of the shortest of four long lines (i.e., L5) and the longest of the four short lines (i.e., L4). The higher this index, the more participants accentuated the between-category differences at the category boundaries.

\section{Results and Discussion}

To test whether the experimental manipulations induced expected changes in fear we conducted one-way ANOVAs with two orthogonal contrasts. The planned comparison, which opposed label fear-induction condition to both standard label and no label condition (Label-fear $=-2$, Label $=1$, No label $=1$ ) was significant, $F(1,133)=30.70, p=.001, \eta_{\mathrm{p}}{ }^{2}=.18$. Importantly, the orthogonal contrast, opposing standard label and no label condition (Label-fear $=0$, Label $=1$, no-Label $=-1$ ) was not significant, $F<1$. As expected, participants in the label fear-induction condition reported higher level of fear $(M=2.08, S D=0.72)$ than those in the two other conditions $\left(M_{\text {Label }}=1.43, S D_{\text {Label }}=0.54 ; M_{\text {no-Label }}=1.53, S D_{\text {no-Label }}=0.51\right)$, who didn't differ from each other, $F<1$.

Regarding the test of our main hypothesis the planned comparison, which opposed label fear-induction condition with no label condition (Label-fear $=-1$, Label $=0$, no Label $=1$ ) was significant, $F(1,133)=12.48, p=.001, \eta_{\mathrm{p}}{ }^{2}=.08$, while the orthogonal contrast $($ Label-fear $=1$, Label $=-2$, no Label $=1$ ), testing residual variance, was not $F<1$. As Figure 1 shows, participants in the standard label condition $(M=0.89, S D=0.51)$ had higher differentiation at category boundaries (i.e., they perceived the greater difference between shortest of the long lines and the longest of the short lines) compared to those in no label condition $(M=0.67, S D=$ $0.40)$. More importantly, this accentuation effect was significantly intensified $(M=1.04, S D=0.53)$ when the presence of categorical labels was coupled with the induction of fear (i.e., label fear-induction condition).

Taken together these results are consistent with those reported by previous research and confirm that the mere presence of categorical labels may be sufficient to elicit perceptual accentuation of differences between categories (Corneille et al., 2002; Tajfel \& Wilkes, 1963). Additionally, they also confirm that the accentuation effect can be enhanced in magnitude by emotions associated with the appraisal of 


\section{Figure 1}

Mean Accentuation Scores (With Error Bars Reflecting Two Standard Errors of the Mean) Depending on the Experimental Condition: Label-Fear, Label and No Label Induction

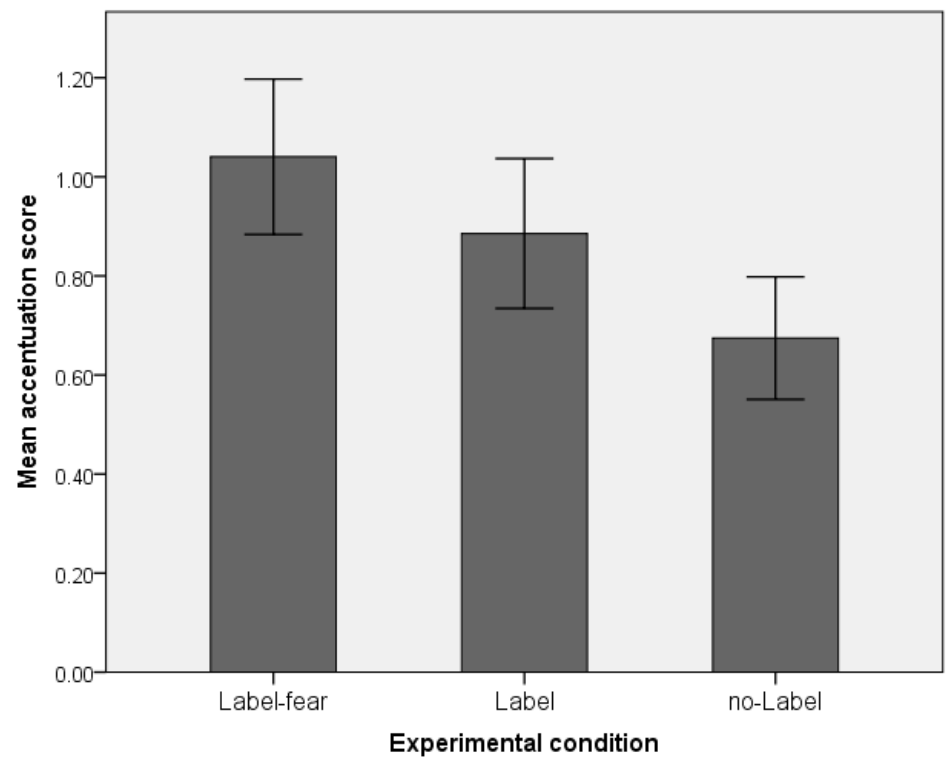

uncertainty. The present study thus replicates and extends past research supporting the idea that reliance on categorical information is more likely to be increased under the condition of uncertainty (Corneille et al., 2002; Petersen et al., 2014; Sherman et al., 2009). More importantly, this is the first study (at least to our knowledge), which shows that emotions could play a determining role in accounting for this phenomenon. In addition, it is important to note that past research on perceptual accentuation mostly involved participants from North American and West-European countries. Given that no similar studies were conducted on the East-European samples our finding also provides a cross-cultural validation of past research, demonstrating that categorical accentuation could be observed in non-Western cultural contexts as well.

Although we found that fear induction enhanced categorical accentuation our study lacks the information about corresponding cognitive appraisals. As such we offer only partial evidence in favour of our hypothesis. To address this issue, future studies should include a valid measure of subjective task uncertainty (e.g., Tiedens \& Linton, 2001), which would allow for direct insight into the underlying processes of the expected emotional effects. In addition, future research should extend present findings focusing on other uncertainty-related emotions such as hope or sadness, which are expected to produce similar accentuation effects as fear. In a similar vein, it would be interesting to explore the potential influence of the emotions, which are theoretically associated with an elevated sense of certainty such as anger. If certainty 
appraisal plays an important role, then these emotions should lead to accentuation reduction. Finally, future research should consider the conceptual replication in the context involving judgments on social stimuli (e.g., Levin \& Banaji, 2006). To further enhance the ecological validity these studies could investigate the potential effects of real-life emotional triggers such as social threat.

\section{References}

Bagneux, V., Bollon, T., \& Dantzer, C. (2012). Do (un)certainty appraisal tendencies reverse the influence of emotions on risk taking in sequential tasks? Cognition and Emotion, 26(3), 568-576. https://doi.org/10.1080/02699931.2011.602237

Corneille, O., Klein, O., Lambert, S., \& Judd, C. M. (2002). On the role of familiarity with units of measurement in categorical accentuation: Tajfel and Wilkes (1963) revisited and replicated. Psychological Science, 13, 380-383. https://doi.org/10.1111/14679280.00468

Eiser, J. R., \& Van der Pligt, J. (1982). Accentuation and perspective in attitudinal judgment. Journal of Personality and Social Psychology, 42(2), 224-238. https://doi.org/10.1037/ 0022-3514.42.2.224

Foroni, F., \& Rothbart, M. (2011). Category boundaries and category labels: When does a category name influence the perceived similarity of category members? Social Cognition, 29(5), 547-576. https://doi.org/10.1521/soco.2011.29.5.547

Foroni, F., \& Rothbart, M. (2013). Abandoning a label doesn't make it disappear: The perseverance of labeling effects. Journal of Experimental Social Psychology, 49(1), 126-131. https://doi.org/10.1016/j.jesp.2012.08.002

Goldstone, R. L. (1995). Effects of categorization on color perception. Psychological Science, 6, 298-304. https://doi.org/10.1111/j.1467-9280.1995.tb00514.x

Hugenberg, K., \& Sacco, D. F. (2008). Social categorization and stereotyping: How social categorization biases person perception and face memory. Social and Personality Psychology Compass, 2, 1052-1072. https://doi.org/10.1111/j.1751-9004.2008.00090.x

Krueger, J., \& Clement, R. W. (1994). Memory-based judgments about multiple categories: A revision and extension of Tajfel's accentuation theory. Journal of Personality and Social Psychology, 67(1), 35-47. https://doi.org/10.1037/0022-3514.67.1.35

Lang, P. J., Bradley, M. M., \& Cuthbert, B. N. (1995). International affective picture system (IAPS): Digitized photographs, instruction manual and affective ratings. The Center for Research in Psychophysiology, University of Florida.

Levin, D. T., \& Banaji, R. (2006). Distortions in the perceived lightness of faces: The role of race categories. Journal of Experimental Psychology: General, 135, 501-512. https://doi.org/10.1037/0096-3445.135.4.501

Lerner, J., \& Keltner, D. (2001). Fear, anger, and risk. Journal of Personality and Social Psychology, 81(1), 146-159. https://doi.org/10.1037/0022-3514.81.1.146 
Lu, J., Xie, X., \& Zhang, R., (2013). Focusing on appraisals: How and why anger and fear influence driving risk perception. Journal of Safety Research, 45, 65-73. https://doi.org/10.1016/j.jsr.2013.01.009

Petersen, S., Schroijen, M., Moelders, C., Zenker, S., \& Van den Bergh, O. (2014). Categorical interoception: Perceptual organization of sensations from inside. Psychological Science, 25, 1059-1066. https://doi.org/10.1177/0956797613519110

Schaefer, A., Nils, F., Sanchez, X., \& Philippot, P. (2010). Assessing the effectiveness of a large database of emotion-eliciting films: A new tool for emotion researchers. Cognition and Emotion, 24, 1153-1172. https://doi.org/10.1080/02699930903274322

Sherman, D. K., Hogg, M. A., \& Maitner, A. T. (2009). Perceived polarization: Reconciling ingroup and intergroup perceptions under uncertainty. Group Processes \& Intergroup Relations, 12(1), 95-109. https://doi.org/10.1177/1368430208098779

Smith, C. A., \& Ellsworth, P. C. (1985). Patterns of cognitive appraisal in emotion. Journal of Personality and Social Psychology, 48, 813-838.

Tajfel, H., \& Wilkes, A. L. (1963). Classification and quantitative judgement. British Journal of Psychology, 54, 101-114. https://doi.org/10.1111/j.2044-8295.1963.tb00865.x

Tiedens, L. Z., \& Linton, S. (2001). Judgment under emotional certainty and uncertainty: The effects of specific emotions in information processing. Journal of Personality and Social Psychology, 81, 973-988. https://doi.org/10.1037/0022-3514.81.6.973

Whitson, J. A., Galinsky, A. D., \& Kay, A. (2015). The emotional roots of conspiratorial perceptions, system justification, and belief in the paranormal. Journal of Experimental Social Psychology, 56, 89-95. https://doi.org/10.1016/j.jesp.2014.09.002

\section{Emocionalne odrednice naglašavanja razlika između kategorija}

Cilj je ovoga istraživanja bio ponuditi preliminarni dokaz o ulozi emocija povezanih s osjećajem nesigurnosti kod fenomena naglašavanja razlika između kategorija. Zadatak sudionika bila je procjena duljine crta koje su se razlikovale duljinom i kojima je, ovisno o uvjetu, dodijeljena ili nije dodijeljena oznaka koja je ukazivala na pripadnost crta različitim kategorijama. S ciljem ispitivanja emocionalnih odrednica naglašavanja razlika između kategorija uveden je dodatni uvjet s crtama kojima su dodijeljene kategorijalne oznake u kojemu su sudionici bili izloženi indukciji straha (emocije koju teorijski karakterizira procjena niske sigurnosti). Očekivano, u skladu s ranijim istraživanjima, rezultati su ukazali na klasični efekt naglašavanja. Sudionici u uvjetu s podražajima s kategorijalnim oznakama pokazivali su veće razlikovanje među crtama koje su se nalazile na granici definiranih kategorija u odnosu na uvjet s podražajima bez kategorijalnih oznaka. Važno je istaknuti da je taj efekt bio dodatno pojačan u uvjetu u kojemu je kod sudionika induciran osjećaj straha, što jasno sugerira da bi emocije koje su povezane s procjenom nesigurnosti mogle igrati važnu ulogu u fenomenu naglašavanja razlika između kategorija.

Ključne riječi: naglašavanje razlika između kategorija, emocije, kognitivna procjena, nesigurnost

Primljeno: 25. 6. 2020. 